\title{
The Implementation of Character Education and Literacy Culture
}

\author{
Siti Robiyah ${ }^{1 *)}$, Bukman Lian², Syaiful Eddy² \\ ${ }^{1}$ SD Negeri 1 Lingkis \\ ${ }^{2}$ Universitas PGRI Palembang \\ *Corresponding Autor. Email: sitirobiyal@gmail.com
}

\begin{abstract}
The research aims at implementing character education and literacy culture in Public Elementary School (SDN) 2 Lingkis of Jejawi District. The field research with a descriptive approach applied in this study. The research subjects were the principal and teachers of SDN 2 Lingkis of Jejawi District. The data collection methods used were observation, interviews and documentation. Furthermore, the data were analyzed qualitatively by means of data reduction, data presentation and verification, and conclusions. Based on the results, it was found that: the implementation of character education is realized through the inculcation of character values on the artifact layer in school culture; the application of literacy culture in schools is carried out at the habituation stage; the development stage; and the learning stage.
\end{abstract}

Keywords: Implementation, Character Education, Literacy Culture

\section{INTRODUCTION}

The atmosphere of learning activities and the learning process is created to make students can actively develop their potential and have the skills needed for living as a nation and state, having spiritual, religious, self-control, personality, and noble character based on the law year 2003 on the National Education System [1]. Siswoyo et al defines education as humanizing young people. The perfect human being has reason and mind [2].

The world of education is not only used to process human reason and thoughts to become more advanced, but with education it can also improve the character, morals and quality of humans themselves. Education that does not emphasize the aspects of character building creates various problems among students. The above problems that continue to emerge is caused the decline in the quality of character values in students. There are often various acts of violence such as fighting between students, cheating, bullying, various immoral acts, destroying school facilities by students, increasing the use of drugs, and so on [3].

Character education is considered as a solution in dealing with the problem of moralization of the successors of the nation, especially the educated students [4]. The character determines one's personal thoughts and actions did. Good character is an inner motivation to do what is right, according to the highest standards of behavior, in every situation. character building teaches habitual ways of thinking and behaviors that bring individuals to life and work together as a family, community, and state and help them to make decisions that can be accounted for.

Character education has a higher meaning than moral education because it does not teach what is right and what is wrong. More than that, character education instills habits related to the goodness so that students are educated to understand, are able to feel, and want to do the good things [5]. According to Hidayat, character education is a plus-like cultural education which involves the aspects of knowledge (cognitive), feelings (feelings), and action (action). Without the three aspects, then character education is ineffective. The implementation must be done systematically and continuously while being able to distinguish one another [6]. In the stage of raising literacy in schools as an effort to promote literacy in general, it is performed by 3 steps, including: 1) The habituation stage comprising fun reading activities in the school emvironment with the aim of growing interest in reading and reading activities within the school community; 2) The stages of developing reading interest to increase literacy abilities which aims at developing the ability to understand reading related to personal experience, critical thinking, and cultivating communication skills creatively; and 3) Literacy-based learning stage that aims to develop the ability to 
understand text concerning with the personal experience, critical thinking, and to cultivate communication skills creatively by responding to the text.

Regarding the application of character and cultural education in schools, there are various obstacles that are usually faced by schools. This is due to various factors including: the curriculum that often changes. The schools are not ready to implement the new curriculum. Beside, the condition of teachers who do not meet the requirements at the level of education and the incomplete school facilities and student problems cause the decline in social manners and moral ethics in school life. This case impacts in a number of negative views that are very disturbing to society.

Based on the preliminary interview with one of teachers at SDN 2 Lingkis, it was found that the teachers the teachers had carried out character education obtained from the teacher working group (KKG). They had not yet received specific socialization previously. However, the teachers still have obstacles in choosing the right characters to be instilled in each lesson because there are many character values that must be instilled in students.

Therefore, referring back to the government's declaration to create literate society through education units, it is necessary to reconsider the current implementation of the school literacy program to continue to be optimized so that the goals can be achieved. Through this research at SDN 2 Jejawi Subdistrict, the researcher focused on the reading culture of SDN 2 Jejawi Subdistrict and the student character education that include honesty and discipline. By doing so, it is hoped that the declaration of character education in schools can be realized.

\section{METHODS}

This study uses a descriptive approach field research that seeks to reveal the management of school principals in improving the competence of SDN teachers in Jejawi District. The research subjects in this study were the principal and teachers at SDN 3 Lingkis of Jejawi District. The data collection methods used were observation, interviews and documentation. After the data were obtained, the validity of the data was checked by trying to compare the information given by the informant and the data from the observations with the results of the interview. Furthermore, the data were analyzed qualitatively by means of data reduction, data presentation and verification and drawing conclusions.

\section{RESULTS AND DISCUSSION}

a. Implementation of Character Education in SDN 2 Lingkis of Jejawi District

The implementation of character education at SDN 2 Lingkis is carried out in the school curriculum which is valid for one school year. Character education the school involves all components of education stakeholders, namely the role of the principal and all teachers in implementing character education methods, implementing extracurricular activities, empowering facilities and infrastructure, financing, and work ethic of all school members. The research is focused only on how the principal and teachers implement the character education and how students can apply it.

Based on the results, it can be interpreted that SDN 2 Lingkis, Jejawi District is planning the character education systematically. The plan is in the form of a character education in a design programmed into the school curriculum including the character values. According to Hasanah [7], the value of character education in schools as a strong base that will help potential students is internalization intensively through example, wisdom, and harmony in both intra and extra-curricular programs. The school has become too preoccupied with academic goals, favoring intellectual, mental, and moral intelligence while marginalizing character growth. It may be inferred that the nature of human nature is expressed in emotions, behaviors, desires, sentences, and acts dependent on moral rules, rules, manners, history, and traditions, and is identified with the Almighty God, ourselves, our fellow human beings, the environment, and nationality.

In addition, the support for the facilities and infrastructure to the program socialization is also prepared for school residents and parents. From the interviews, it can be seen that the principal and all teachers have implemented character education at SDN 2 Lingkis by implementing exemplary and habituation of advising. The principal as a leader and educator in the school must be a model for all teachers and students in schools. Prayitno [7] argues that examples must be part of the pillar of authority in the educational process. Example is the pinnacle of the student-teacher performance. The whole appearance of the educator is based on acceptance and recognition, affection and tenderness, in strengthening forms and educating thoughtful action, which is entirely positive and normative.In character education in schools, all components (stakeholders) must be involved, including the components of education itself, namely curriculum content, learning and assessment processes, quality of relationships, handling or management of subjects, school management, implementation of activities, empowerment of infrastructure, financing, and the work ethic of all residents and the school environment [8].

Based on the results of the description of the data that has been obtained from the field, it can be concluded that the implementation of character education for students at SDN 2 Lingkis has been running quite well. Although there found some students who are still stubborn about the implementation of congregational prayers and ignore school regulations. Students who have good character already have good habits or the willingness to do goodness that can be influenced by education and the environment (external factors). Likewise, students who have bad habits or do 
not have the will to have good character will be influenced by education and the environment (external factors).

b. The implementation of Literacy Culture at SDN 2 Lingkis, Jejawi District

The implementation of literacy culture at SDN 2 Lingkis includes three stages. The first step is the application of a habitual literacy culture. The second step is the application of a developmental literacy culture. The last one is the application of a learning literacy culture carried out to achieve predetermined goals through the use of human resources and other resources.

The school literacy movement program is carried out in 3 stages, namely the habituation, development and learning stages. In the habituation stage, the literacy movement program is carried out by reading activities for 15 minutes before the lesson begins, namely reading textbooks. The library also participates in the activity of reading aloud and reading silently. The stories will be read by the librarian, and then students will be given the opportunity to give comments regarding the stories that have been read.

The development phase is carried out literacybased activities at school holidays such as April books expose in collaboration with publishers. It is held during April regularly every year to commemorate Kartini and Maulid Nabi days. Next, there are rewards for students who diligently borrow books and visit the library.

In the learning stage, the students are asked to write down the reading activities containing a summary of the stories. Students have read strategies for building a literacy culture including growing awareness of the importance of reading, a culture of reading in schools, optimizing the role of libraries, getting used to gifts in the form of books, and appreciate some papers.

The study is similar to what Beers, et al. suggested [9]. They wrote A Principal's Guide to Literacy Instruction conveying some strategies for creating a positive literacy culture in school. The first is conditioning the physical environment of the school literacy friendly. Schools should be "parks" therein, Indonesian children get a full learning atmosphere challenge and fun, therefore it is expected that the physical environment at school it needs to look literacy-friendly and conducive for learning. The school is going foster interest in reading and writing supposed to be able to fulfill the means and infrastructure for books and reading materials by optimizing library functions schools, providing reading corners in each classroom and in several other areas at school. The next is Strive for school as literate academic environment. Physical, social, and affective environment closely related to the academic environment. Schools should work together between residents schools in carrying out literacy programs. The principal is the leader should have insight and vision literate that is able to facilitate diversity of understanding in order to achieve it mutual success in pursuing school as an academic environment literate. The last is seeking Environmental Cooperation Social and Society in Movement School Literacy. Social and community environment should be involved in literacy program which is built through the communication model and the interaction of all school components active. Fundraising in an effort fulfillment of reading material can be done through active interaction of parents, alumni as well as the cooperation of a number of parties such as School committee forums and business entities who have attention to education especially literacy.

So, in fostering student interest in reading and writing through Literacy Culture is a good first step to form and develop insight skills and knowledge of the thoughts of elementary school children. Because literacy culture itself is the most important supporting factor in helping to create interest in reading and writing for elementary school children. Not only the role of the government, school principals, teachers and the surrounding environment, but the role of parents is also very important in guiding the development and growth of children's abilities in creating works of literacy culture. Although literacy culture gives significant good lead to students, the backward supply of facilities and infrastructure to support literacy culture such as books, libraries, comfortable spaces for reading will also affect the process of literacy culture [10].

c. Obstacles in the Implementation of Character Education and Literacy Culture at SDN 2 Lingkis

Based on the descrition above, it can be concluded that character education is a process of character building in students which is a systematic unit of integration through teaching and learning activities, extracurricular activities, creating school culture, and implementing it in the family and community environment. If all of these components do not run well, students will not be able to carry out character education in their lives.

The obstacles in implementing character education at SDN 2 Jejawi District are found in some parents who still have not used the character education implemented in schools. Some values that have been cultured at school are often forgotten when they get home. At school the students have been accustomed to be the character, then at home they have to be supervised by the parents. Sometimes after being at home the character values that have been applied are often forgotten. For example, the activity of praying at home, the majority of parents work so that the lack of supervision of children's prayer activities at home. Even though at school the students have been accustomed to praying, they are not supervised at home. This is the importance of parents' role at home.

Parents less care about character education activities in schools because they take to much trust in 
schools. When invited to school for a meeting regarding their child's development, the parents never attended. Parents who trust the school too much will follow all decisions made by the schools. The parents should put a little suspicion on the school so that they care about their children's activities at school. Lack of parental understanding of the importance of character education enable parents only see the success of their child through the academic values in the learning activities. The awareness of students is still lacking. Students of Elementary school age tend to like playing. They have high curiosity and are in a developmental stage. Thus, it is necessary to have supervision and reprimands when students break the rules. Lack of teachers' understanding of the character education program that has been launched makes the teachers do not consistently give punishment or reprimand when students commit violations.

Based on the results, it can be concluded that the great hope of the school in the future is an increase in character education programs shown by all school members. The character education becomes a common interest that the schools can improve achievement both in academic and non-academic fields. Most importantly, the formation of good character and personality is created in the family, school and community environment for the present and the future.

\section{CONCLUSION}

The implementation of character education is realized through the inculcation of character values in school culture. It is done through the provision of adequate facilities, facilities and infrastructure to support various activities in school programs, and those habits in everyday life at school. These school programs are designed to shape the character of students through activities in the school environment. The program is supposed to perform both consciously and unconsciously so that the students can familiarize themselves with the character values planned by the school. Character education in school culture at SDN 2 is basically implemented in the value and belief layer and the artifact layer. Planning for character education in the school culture consists of an analysis of the conditions and potential of the school to determine. The character values developed are religious values, honest values, and discipline values. Constraints or inhibiting factors in the process of implementing character education at SDN Lingkis originates from the teachers, students, and parents.

The application of literacy culture in SDN 2 Lingkis consists of three stages namely habituation, development, and the learning. At the habituation stage, the students of SDN 2 Lingkis perform the habituation on the literacy movement program with reading activities of 15 minutes before the lesson began. The activity is reading textbooks. The library participates in reading activities such as reading aloud and silent reading. The story will be read by the librarian then students will be given the opportunity to give comments about the stories that have been read. The development activity includes routinely carrying out April booksexpo. It is the time to give rewards to students who are diligent in borrowing books and visiting the library. The last stage, students are asked to write down activities which contain a summary of the stories students have read. This is the strategies for building literacy culture.

The obstacles in the implementation of character education at SDN 2 Lingkis of Jejawi District are found in some parents who still have not used the character education that has been implemented in the school. Some values that have been cultured at school are often forgotten when they get home. At school the students have been accustomed to some good characters, then at home they have to be supervised by the parents. Sometimes after being at home the character values that have been applied are often forgotten.

\section{REFERENCES}

[1] Undang-Undang No. 20 Tahun 2003 Tentang Sisdiknas

[2] Siswoyo, D. (2011). FakultasImu Pendidikan.Yogyakarta: UNY Press.

[3] Lickona, T. (2013). Pendidikan Karakter: Mendidik Untuk Membentuk Karakter Bagaimana Sekolah Dasar Mengajarkan Sikap Hormat dan Tanggung Jawab. Jakarta: Bumi Aksara.

[4] Suryanti. I dan Arafat. Y. (2018). Implementasi Pendidikan Karakter Disiplin dan Tanggung Jawab di SD Negeri 18 Air Kumbang.Jurnal Manajemen, Kepemimpinan, dan Supervisi Pendidikan.Volume 3, No. 2, Juli-Desember 2018

[5] Suprihatiningrum. J(2012). SrategiPembelajaran. Yogyakarta :A-Ruzz Media

[6] Hidayat. F (2010). Pendidikan Karakter: Membangun Peradaban Bangsa. Surakarta: Yuma Pustaka.

[7] Prayitno. (2010). Pendidikan Karakter Dalam Pembangunan Bangsa. Medan: PPs Universitas Negeri Medan

[8] Hasanah, U. (2016). Model-model Pendidikan Karakter di Sekolah. Al-Tadzkiyyah: Jurnal Pendidikan Isalam. 2 (7). pp. 18 - 34.

[9] Beers, et al. (2009). A Principal's Guide to Literacy Instruction. New York : Guilford Press

[10] Jatnika, S.A (2019). Budaya Literasi untuk Menumbuhkan Minat Membaca dan Menulis. Indonesian Journal of Promary Education. 3 (2). pp. 1 -6. 